\title{
Juventude e escolarização: propostas para práticas pedagógicas
}

\author{
Mariana Cunha Bhering ${ }^{1}$
}

\section{Resumo}

A pesquisa terá como foco o estudo da juventude e educação escolar no Brasil. Serão questões norteadoras: quais temas e metodologias aparecem nas produções de teses e dissertações nos anos de 2011 e 2012 sobre o tema juventude e escola no portal da Coordenação de Aperfeiçoamento de Pessoal de Nível Superior? Quais as concepções sobre juventude abordadas nos estudos? Quais indicativos de propostas para prática escolar: aprimoramento, formulações?

Assim, perpassa no estudo compreender qual a concepção de juventude nas produções acadêmicas e suas implicações em práticas educativas.

\section{Metodologia}

A pesquisa será do tipo qualitativa, que terá como técnica de tratamento de dados a análise de conteúdo. A partir da seleção de teses e dissertações nos anos de 2011 e 2012.

Este estudo utiliza o portal de teses e dissertações da Coordenadoria e Aperfeiçoamento de Pessoal de Nível Superior - CAPES. Dos 753 registros denominados juventude no site da CAPES, 198 são da área de conhecimento em educação e 171 do programa de educação. A partir da leitura dos

\footnotetext{
1 marybhering@gmail.com - (31) 364672 58/ (11) 994070175. Mestranda em educação Universidade Federal de São Carlos.
} 
resumos, desses 171 dissertações e teses, 50 estão relacionados à educação formal e juventude. A partir desse ponto relacionamos os temas mais pertinentes ao desenvolvimento da pesquisa, as 50 dissertações relacionadas à juventude e escola, encontram-se concentradas no ano de 2011 e 2012.

A partir do levantamento das 50 teses e dissertações relacionadas ao tema, realizar as fichas de leitura. Organização de fichas de leitura que registre e analise: referência completa, tema, tipo de pesquisa, metodologia de pesquisa, sujeitos, resultados do estudo, base teórica e indicações para práticas educativas ou políticas públicas. Os estudos serão organizados em categorias e subtemas de analise são eles a princípio: aprendizagem, sentido da escola, e tecnologia.

\section{Fundamentação Teórica}

A juventude é um conceito é uma construção sócio-histórica, cultural, política e relacional a sociedade contemporâneas. $\mathrm{Na}$ sociedade contemporânea, de fato, a juventude não é somente uma condição biológica mas uma definição cultural. Incerteza, mobilidade, transitoriedade, abertura para mudança todos os atributos tradicionais da adolescência como fase de transição, parecem ter se deslocado bem além dos limites biológicos para tornarem- se conotações culturais de amplo significado que os indivíduos assumem como parte de sua personalidade em muitos estágios da vida (MITTERAUER, 1986; ZIEHE, 1991).

Os autores Margullis; Arrusti (1996), Carrano (2005) e Abramo(1997), falam do conceito de juventude como sinônimo de juventudes, pois, evidenciam que a juventude é variável de acordo com cada contexto político, econômico e sócio cultural. 
Ao pensar juventude e ambiente escolar, temos como eixo, analisar a relação jovem e educação escolar a partir das temáticas estudadas nas teses e dissertações. Entre as temáticas abordadas no estudo estão: sentido da escola, violência, fracasso escolar e meios de aprendizagem: tecnologia e outros.

Assim, se faz necessário também refletir sobre a função social da escola e cultura escola. A abordagem conceitual sobre juventude se completa com a abordagem sobre a concepção de aluno e adolescente, apresentados nos estudos que serão analisados.

A educação não transmite a cultura, entendida como um patrimônio simbólico unitário e coerente, ela transmite algo da cultura, alguns elementos da cultura, nos quais não há necessariamente homogeneidade, pois, pode originar-se de várias fontes. (FORQUIN, 1993). O aprendizado de uma cultura não deve se limitar a intuição escolar. O que se ensina é uma parte idealizada da cultura que compõe o objeto de uma aprovação social (FORQUIN, 1993)

Neste sentido, a cultura escolar que precisa constantemente ser pensada, não se sobrepõe os saberes dos estudantes, denominado por Freire (1991) de saber de experiência feito.

\section{Considerações Finais}

Muitos estudos vêm indicando o aumento da pesquisa em nas ciências sociais sobre juventude de escola. Abramo reforça que somente na década de 90 é que tem ganhado certo volume de números de estudos sobre juventude para considerar os próprios jovens e suas experiências, suas percepções, formas de sociabilidade e atuação. P. 25 (ABRAMO, 1997) 
A pesquisa na temática sobre juventude vem mostrando por tanto, uma atenção maior da área da educação para o tema. Dessa maneira, torna -se necessário mais trabalhos que investigue e sistematize as produções acadêmicas, suas contribuições e indicativos para políticas públicas e práticas educativas.

Com a ampliação do ensino básico obrigatório até o ensino médio, mudou os velhos "modos de fazer as coisas" nas instituições. Anteriormente, na formação das elites, os "mais capazes" concluíam o ensino médio e adquiriam o direito de entrar na universidade, período que a entrada era garantida apenas com a conclusão do ensino médio. (FANFINI,2000 )

Deste modo, a educação escolar básica continua em um processo de ampliação, assim, a preocupação de repensar práticas pedagógicas precisa superar a prática fácil da repetência e da exclusão. Temos com hipótese que as produções acadêmicas recentes possuem indicativo de melhorias de práticas pedagógicas

Palavras Chave: juventude, educação escolar e prática educativas

\section{Referências}

ABRAMO, Helena Wendel. Considerações sobre a tematização social da juventude no Brasil. Revista Brasileira de Educação. N.6. 1997.

AUBERT; Adriana, FLECHA; Ainhoa, GARCIA; Carme, FLECHA; Ramón e RACIONERO; Sandra. Aprendizaje dialógici en la sociedad de la información. Hipatia Editorial, Barcelona, 2008.

BARDIN, Laurence. Análise de Conteúdo. Edições 70, Lisboa, 1977. 
BRASIL, Ministério da Educação. Documento orientador do Pacto Nacional pelo fortalecimento do Ensino Médio. 2013 Disponivel em < http://pactoensinomedio.mec.gov.br/index.php?option=com_content\&view=article\&id= 41\&Itemid=116> Acesso em 5.ago.2014.

BRASIL. EMENDA CONSTITUCIONAL N ${ }^{\circ}$ 59, DE 11 DE NOVEMBRO DE 2009 Disponível em: $<$ http://www.planalto.gov.br/ccivil_03/Constituicao/Emendas/Emc/emc59.htm) Acesso em: 15. ago. 2014.

BRASIL. Estatuto da Juventude. LEI No 12.852, DE 5 DE AGOSTO DE 2013. Disponível em < http://www.planalto.gov.br/ccivil_03/_Ato20112014/2013/Lei/L12852.htm> Acesso em: 16.ago.2014

BOURDIEU, Pierre. A "juventude" é só uma palavra in Questões de Sociologia. Editora Fim do Século. Lisboa. 2003.

CARRANO, Paulo César Rodrigues. Identidades juvenis e escola. in Construção coletiva: contribuições à educação de jovens e adultos. — Brasília : UNESCO, MEC, RAAAB, 2005.

FREIRE, Paulo.Pedagogia do oprimido.17ª ed. Rio de Janeiro, Paz e Terra, 1987.

Pedagogia da Esperança. Um Reencontro com a Pedagogia do Oprimido.Rio de Janeiro: Paz e Terra, 1992.

FORQUIN, Jean-Claude. Escola e cultura. In: Escola e cultura: as bases sociais e epistemológicas do conhecimento escolar. Trad. Guacira Lopes Louro. Porto Alegre: Artes Médicas, 1993.

GIMENO SACRISTÁN, J. O que significa o currículo? In: (org.). Saberes e incertezas sobre o currículo. Tradução: Alexandre Salvaterra. Porto Alegre: Penso, 2013, p. 16-35.

MARGULIS, M.; URRESTI, M. (1996). La juventud es más que una palabra. Ensayos sobre cultura y juventud (Cap 1). Buenos Aires: Editorial Biblos.

(1998). La construcción social de la condición de juventud. En H. Cubides; M. Laverde y C. Balderrama (Ed.). Viviendo a Toda. Jóvenes, territorios culturales y nuevas sensibilidades, (pp 3-21). Bogotá: Siglo del Hombre. 
SPOSITO, Marilia (Coor.). O Estado da Arte sobre juventude na pós-graduação brasileira: Educação, Ciências Sociais e Serviço Social (1999-2006). Argumentum: Belo Horizonte. 2009.

SPOSITO, Marília Pontes Sposito. CARRANO, Paulo César Rodrigues. Juventude e políticas públicas no Brasil. Revista Brasileira de Educação. N. 24. 2003.

FANFANI Emilio Tenti. Culturas jovens e cultura escolar. In: Seminário "Escola Jovem: um novo olhar sobre o ensino médio", 2000, Brasília. Anais eletrônico

Anais Eletrônico. Disponível em: <http://www.mec.gov.br/semtec/ensmed/artigosensaios.shtm> Acesso em: 11 ago.2014.

WILLIAMS, Raymond. Cultura. Trad. Lólio Lourenço de Oliveira. Rio de Janeiro: Paz e Terra, 1992. Capítulo 8 (p. 205-231).

$321-361)$

Cultura e sociedade de Caleridge a Orwell. Petrópolis: Vozes, 2011 (p. 